
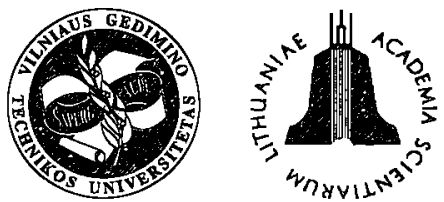

ISSN 1648-4142 TRANSPORT

http:/www.vtu.lt/english/editions

TRANSPORT - 2003, Vol XVIII, No 4, 182-188

\title{
SOCIAL AND ECONOMIC ANALYSIS OF THE DEMAND FOR PUBLIC TRANSPORT IN VILNIUS*
}

\author{
Daiva Griškevičienè, Algirdas Griškevičius \\ Dept of Transport Management, Vilnius Gediminas Technical University, Plytines g. 27, LT-2016 Vilnius, \\ E-mail:daival@centras.lt
}

Received 200306 23; accepted 20030630

\begin{abstract}
To determine the demand for public transport on the market, a survey was conducted in $2001-2002$ concerning the situation in the suburban zones of newly - built up districts where public transport is either inaccessible or poorly developed. The analysis was based on major social and economic factors determining the demand for transport. They are: demographic structure and development, restructuring of productive forces and space planning; employment and unemployment; income and poverty; social insurance, pensions and welfare; the household structure; income and expenditures; mobility of the inhabitants and motorization. The accessibility of transport services to passengers and the choice of transport facilities is closely related to their purchasing power.

The offer of public transport services is lower than the demand, especially in the suburbs. As a result, the competition of automobiles is very strong there: the preference given to a car is determined by inaccessibility of public transport on the route for $22 \%$ of the inhabitants, while for $20 \%$ the reason was long way to a bus stop or large intervals in the schedule of public transport facilities.

Based on the results obtained, the public transport system in Vilnius should be developed along three main lines: 1) raising the quality of public transport provided on fixed routes; 2) revising and updating the system of fares; 3 ) integrating the suburban public transport system into the central city transport system. These are the priority tasks associated with general goals of improving the system of public transport so that it could satisfy the needs of the passengers in the city.
\end{abstract}

Keywords: public transport, routes, demand, supply, suburban, service quality.

\section{Introduction}

The most serious problems associated with public transport are encountered in cities where the most heavy traffic and powerful transport facilities are found but the networks of roads and the existing routes can not satisfy the requirements. In addition, many transport facilities are worn out, and, therefore, do not satisfy the demands of passengers. As a result, a number of technological, technical, organizational and commercial problems arise which should be solved as soon as possible. However, the insufficient financing is the main obstacle on the way of finding the solution to these problems. Though urban traffic is several times as heavy as that between towns and cities, the problems of improving urban traffic organization, expansion of its infrastructure and the support of public transport are often considered a matter of minor importance,. In a transition period to market economy, the efforts made to maintain public transport were neither financially or methodologically supported. Unfor-

\footnotetext{
* Discussion of results of programme "Transport: technolo-
} gies, economic, environment, health" tunately, the authorities often find the arguments to support the requirements of transport service firms to raise the fare of public transport as a means to solve the problem of financing this sector.

Public (passenger) transport in Lithuania is oriented at the inhabitants of average and lower income, because the middle class has not been formed during the ten years of Lithuania's independence. Declaring the support of public transport, the state shows that it is concerned with the problem of providing transport services to the inhabitants. Unprofitable public transport is still an unsolved problem. It is associated with the demand for public transport services and purchasing power of the inhabitants. This is not an economic but a social problem as well. To determine the adequate structure and capacity of the transport system, and the amount and cost of transport services, it is necessary to study the market, as well as its demand and supply. For this purpose, a master plan of Vilnius has been developed in accordance with the general territory planning of the Republic of Lithuania, and the state of the transport system and its management as well as the offer of transport services have been investigated. 
In $2001-2002$, the studies aimed to explore the Vilnius market for determining passengers demand for public transport services and their purchasing power related to it and to help harmonize the demand of urban and suburban inhabitants for the above services with the actual supply of passenger transportation were conducted by the authors of the present paper. The investigation of the market demand for transport services by the inhabitants from social and economic perspectives supplemented with the data obtained in the previous analysis of public transport services and the mobility of inhabitants is intended to harmonize the quality and cost of transport services provided.

\section{The Analysis of the Passengers Market for Public Services and its Potential}

A number of various factors determine the mobility of inhabitants and the demand for transport services, particularly in the transition period when new economic relations, lifestyles, etc. being formed promote the formation of new social needs of the inhabitants [1-4].

The research has proved that the choice of travel depends on the goals, financial resources and the availability of transport facilities for the inhabitants.

With respect to theoretical considerations, major factors may be divided into the following groups incorporating [5-8]:

1) the factors related to space planning and residential areas,

2) macroeconomic and social factors,

3) factors related to purposes of travel and means of transportation,

4) factors associated with purchasing power of passengers.

However, the above groups are closely interrelated, thereby complicating the problem solution and making the analysis of the particular group practically impossible without considering the influence of some other factors.

\section{tial area.}

1) Factors related to space planning and residen-

The spatial planning of Vilnius plays the leading role in the formation of the network of streets and public transport system as well as its efficiency. Major administrative, business, shopping, entertainment and catering centers are found in the downtown and the adjacent districts. The inhabitants and residents of these zones are provided with various transport facilities, therefore, their everyday journey does not take much time and effort.

In the middle zone of the city (around the downtown) the choice of passengers is not so wide, being restricted to public transport and route schedule. Radial layout of the streets and natural obstacles (river bridges, hills, green areas, etc.) also play a role in providing trans- port services to the inhabitants. Radial and tangential highways are used not only for servicing the residents of these areas but for connecting more distant districts with the center of the city and for making a detour around it. Therefore, they perform a dual function, and the traffic is very heavy there in rush hours.

During the last decade the cities were expanding rapidly. The former rural approach roads and detours have become major highways of newly - built districts, lacking, however, the adequate engineering facilities, the appropriate pavement, rainfall run - off and lighting systems, etc. Other engineering utilities, such as water supply and sewerage systems are also inadequate in these districts. Therefore, such roads are hardly suited not only for public transport but for automobile transport as well.

\section{2) Macroeconomic and social factors.}

Based on research data and the studies of social problems [9-13], the priority factors affecting the mobility of the inhabitants in urban areas and in the state as a whole and limiting social demand and possibilities of making a choice were selected for the analysis. They are as follows:

a) demographic structure and development. After regaining the independence, the natural growth of the population of Lithuania was considerably decreasing, falling to the lowest level in $1993-1994$. The urban population of the country reaches $68,1 \%$, with the urbanization increasing on account of rural inhabitants. People able to work make $59,1 \%$ of the inhabitants, while under age people and pensioners make $20,7 \%$ and 20.2 $\%$, respectively. During the decade of economic transition period the migration of the population increased: some people left Lithuania for political, others for economical reasons. However, the flow of immigrants also increased. It decreased in 2000 , being followed by the increasing emigration to the former Soviet Union republics, Estonia and Latvia. The worsening economical and social conditions promoted the emigration of good specialists, students and workers to Western countries.

b) restructuring of productive forces and transport relations. During the last decade, major enterprises of Lithuania were restructured: some of them were divided into several smaller enterprises, while others were closed. New private large, medium and small firms emerged. The market of products and services has experienced the regrouping of labour force, capital and investments. This, in turn, brought to life new requirements to transport system and services as well as to the conventional transport routes. A large gap was formed between the rapid development of towns and settlements, trade, manufacture and the construction of residential areas in the suburbs and transport development, road construction and the development of public transport services there.

3) Purposes of travel and transport facilities used: 
a) travel and motorization. In 20012,83 mln passengers were carried by public transport along the international routes and $353,08 \mathrm{~min}$ passengers - along the national routes. In the cities, $147,2 \mathrm{mln}$. people were carried by bus, while $164,3 \mathrm{mln}$ were transported by trolley - buses (Fig 1). Because of the high rate of motorization, public transport has lost a part of passengers. In 2001, the degree of motorization of the population reached 304,0 auto/1000 inhabitants, with 0,8 automobile per household. The motorization boom in Lithuania was caused by the flood of old relatively cheap Western made cars on the market.

The mobility of the inhabitants increased not only on account of commuters but because people began to travel more at the weekends and in their leisure time. Even seasonal travel fluctuations became not so sharp. Now these fluctuations correspond to the variations of expenditures for cultural and recreational purposes.

b) the influence of communication and information technologies. The introduction of new information technologies greatly influences the mobility of the population. Unfortunately, the number of personal computers in the households is rather small and the use of the Internet is not wide either. In 2001, only 6 out of 100 households were provided with personal computers, while nearly half of them had automobiles. The figures for Vilnius are somewhat higher. The emergence of information technologies and telecommunication will undoubtedly change the lifestyle of people and housekeeping. In future, the role of these new technologies in the households may be more important than that of the automobile and public transport. The survey has shown that urban inhabitants are going to have personal computers in their houses in the near future.

4) Factors related to purchasing power of the inhabitants (passengers):

a) employment and unemployment. In 2001 , there were 1,760 mln people able to work in Lithuania. About 1461 thous. people did any paying job. Two thirds of the employed worked in the cities. Unemployment made $17 \%$ [9] (12,5\% according to labour exchange). Young people belong to the most vulnerable group of population with respect to unemployment. Under the conditions of unemployment and illegal employment, insurance and other taxes and payments have dropped considerably narrowing the scope of state social support programmes and the funding provided by various foundations. Active labour force makes $61,4 \%$, the employment $-54,3 \%$, while unemployment stabilized at $11,5 \%$. Most of the inhabitants are employed in economically active areas such as agriculture and forestry $(19,6 \%)$, manufacturing industry $(17,7 \%)$, trade $(14,7 \%)$, education system $(10,2$ $\%)$, health care and social work $(7,0 \%)$ and transport and construction industry $(6,3 \%)$. In these areas the changes in the proportion of men and women employed may be observed, when the number of women employed is higher because they are usually lower paid than men (Fig 2).

b) earnings and poverty. The structure of the income of a household is as follows: $52,1 \%$ of the income is obtained from working for a wage, $12,2 \%$ is the income of self - employed people, $24,3 \%$ - pensions and other subsidies, $0,3 \%$ - income from the rent and $11.1 \%$ - other kinds of income.

The average monthly net income in the country is $752,9 \mathrm{Lt}$, while in the state sector it is $777 \mathrm{Lt}$ and in the private sector $-729 \mathrm{Lt}$. According to the data obtained (in monetary expression and natural) the average income per capita in a household was $428,0 \mathrm{Lt}$, including $475,2 \mathrm{Lt}$ for one townsman, with up to $50,8 \mathrm{Lt}$ in big cities and 428,8 in towns) and 327,1 for a countryman.

About $16 \%$ of the Lithuanian population live in poverty. In the report on poverty made in 2001 it was stated that $1 \%$ of the people live far below the line of poverty. People belonging to this group of population get less than 1 minimal payment $(260 \mathrm{Lt})$ per month. The main reason of poverty is unemployment, which reached $12,3 \%$ in 2001 . About $7,2 \%$ of the unemployed have not worked for a long time (up to several years). Under the conditions of poverty a family get used to live on subsidies.

c) social insurance, pensions and welfare. Social needs and economic power are also affected by the decrease of birth rate and aging of the population (19\% of the inhabitants are over 60). Therefore, the number of socially supported people is growing in Lithuania, with

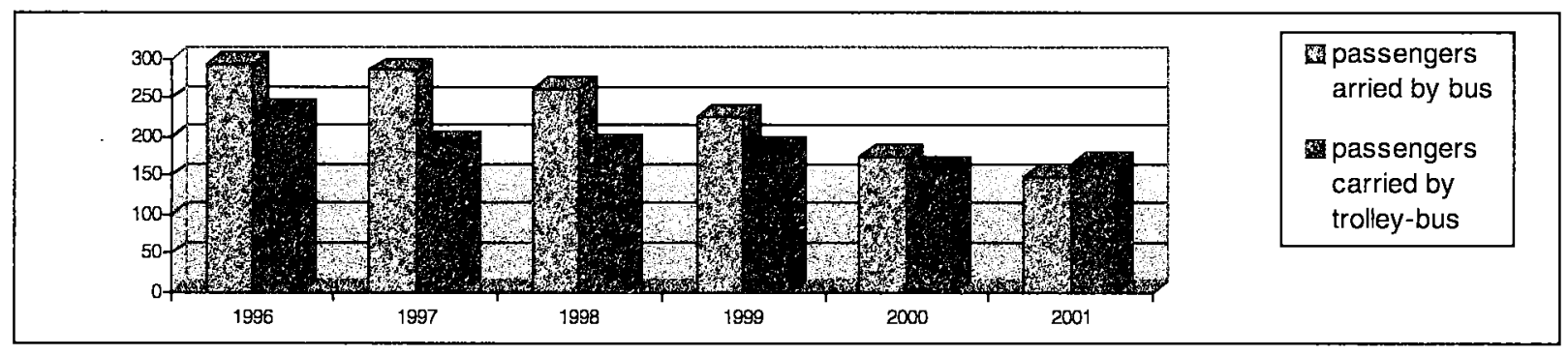

Fig 1. Passengers carried by public transport facilities 


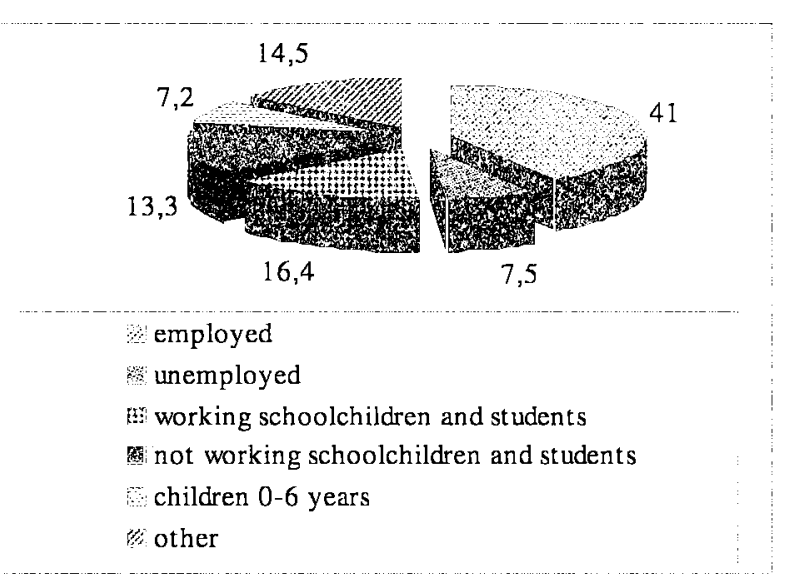

Fig 2. Employed and unemployed inhabitants in 2001

economy problems becoming more acute. The total number of the state social insurance pensions is growing every year (about $20 \%$ per 5 years). When the government increased the age giving the right for a pension, the number of pensioners decreased by $1,6 \%$ (10,5 thous. people). The number of people getting disability pensions has grown by $18 \%$ in the last 5 years, with the employment of handicapped people increasing by $42 \%$. In 2001, the pensions of about $10 \%$ of old - age pensioners were below the average $(317,6 \mathrm{Lt})$. Because of low old - age pensions every sixth pensioner $(15,6 \%)$ was working. The number of poor families bringing up children is growing, especially among young people. The same refers to the asocial families (in 2001, there were 18,114 thous. such families with 40.276 children). The number of passengers who need discount for transport fares is also growing.

d) dwelling and the environment. These factors are considered as most important in overcoming poverty. In 2001 , about $60 \%$ of Lithuanian population were provided with dwellings, which is similar to the state in EU countries. According to a number of rooms per capita $(0,95 \%$ of the room), Lithuania has reached only half of the level achieved in EU countries. However, in recent years the situation has changed for the better. Better well off people are buying new houses and apartments thereby improving their living conditions. On the other hand, this posed some new problems associated with transport services. Families with schoolchildren, students and pensioners usually choose districts where public transport is available.

e) household structure, income and expenditures. A household includes people connected by family or business relations who share the budget and dwelling. In 2001 , there were $21 \%$ of one person households, while $28 \%$ had 2 persons, $22 \%-3$ persons, $18 \%-4$ persons and $8 \%-$ more than 4 persons (Fig 3).

The disposable income of a member of the household varied in accordance with the economic develop-

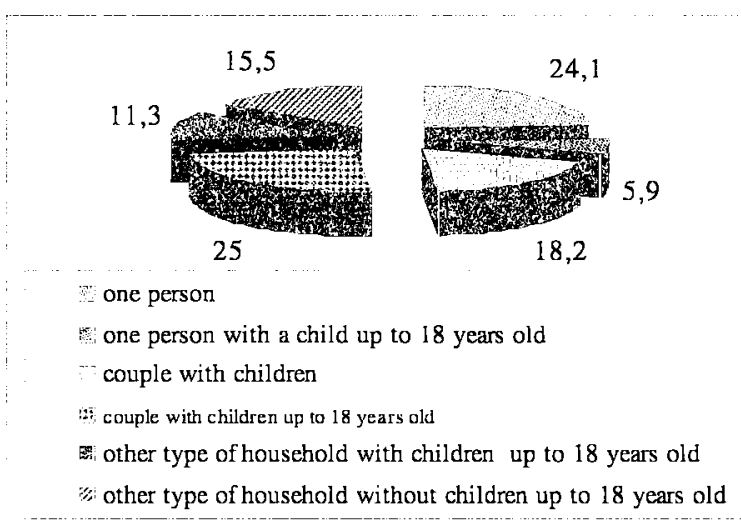

Fig 3. The structure of households, $\%$

ment (in town it reached 465,9 Lt). The sources were mainly work payment and the income of self-employed people. The proportion of work payment is higher for the townsfolk $(67 \%)$ than for villagers $(57 \%)$. The income obtained in working for a wage made $89 \%$ of the total income in town and $51 \%$ in the rural locality. The highest income was obtained by the households mainly engaged in business, trades and other professional activities. A monthly income of one household member was $473 \mathrm{Lt}$.

In 2001, the monthly expenditures of one household member made $451 \mathrm{Lt}$ (443 Lt in town and 323 in the village). They decreased by $5 \%$ compared with those in 1999. The expenses on foodstuffs made $38 \%$. Yearly expenditures of town dwellers on electric power, heating, etc. made $15,2 \%$, while they spent $5 \%$ on the communication, $7 \%$ on clothes and footwear and $5 \%$ on health care (Fig 4).

One household member spent about $8 \%$ on travel, while self - employed spent about $11 \%$ on it. About $42 \%$ of the households owned automobiles ( $79 \%$ of the houses of businessmen). For the households of pensioners, the monthly expenses of one person on transport services made $4 \%$ of the total expenditures. Only $19 \%$ of such households had automobiles.

\section{The Analysis of the Demand for Public Transport Services in Vilnius}

Urban structure and its variation. During the census in 2001, 555 thous. of inhabitants were registered on the territory of Vilnius local government. The territory has expanded by $10 \%$ compared to 1990 , though the population has dropped by 65 thous. inhabitants. The territory has increased up to 402 sq. $\mathrm{km}$ because Grigiškejs region joined Vilnius in 1999. Early in 2001, Vilnius had 589,2 thous. people, with the density of population being 1469,2 inhab./sq. km. In 2000, in built - up districts of Vilnius the population density reached 4250 inhab./ sq. $\mathrm{km}$. The rate of population growth depends on eco- 


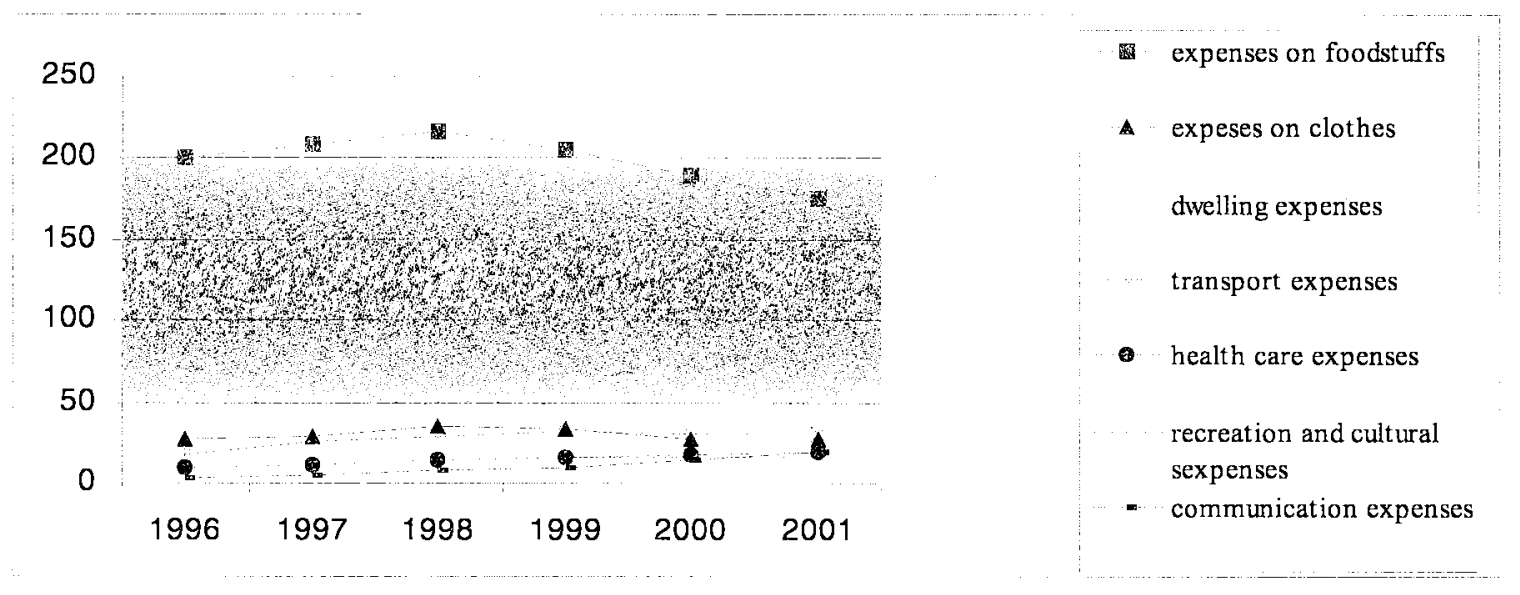

Fig 4. Average consumption expenses 1996-2001 m., Lt

nomic conditions, therefore, it is expected that by 2010 the population will increase only up to 600 thous. people. The main demographic problems are the aging of the population and the emigration of qualified young people.

Growth of the city. The unique lay - out and large economic, social and cultural potential of Vilnius allow for the expansion and growth of its population. According to a master plan, the priority of expansion is given to the central part of Vilnius, because the advantage may be taken from its developed infrastructure and engineering utilities. The old buildings are restructured and new commercial buildings are usually built there.

One family houses are built on the territories of the former villages extending in the Eastern, Northern and Western direction. The owners should themselves improve their living conditions, because the local government has no plans of extending the network of engineering utilities to these districts and has not formed any general urbanization policy yet.

\section{The Analysis of the Needs of Vilnius Residents}

A survey has shown that, for the inhabitants of Vilnius, transport problems are very acute though two thirds of them have adapted to their place of residence. During the last decade, one third of residents have moved to new houses or flats, while about $8 \%$ came to Vilnius from other places. One third of the inhabitants would like to move elsewhere. The most prestigious districts named by the residents were Senamiestis (Old Town), Antakalnis and Žvèrynas, while Lazdynai, Žirmūnai, Karoliniškès, Vilnius suburbs, Naujoji Vilnia, Verkiai are considered attractive by them. Half of the residents associate highly attractive objects with the old town, central and the new town areas as well as with historical zones and green belts. One third of the population give the priority to cultural and entertainment objects.

When evaluating other factors the inhabitants often emphasize that the transport of the city is quite satisfactory. In choosing the place of residence people give the priority to safety, the environment and the availability of public transport facilities. However, the residents of Vilnius are not satisfied with the state of many streets, squares and yards. Besides, it is not always safe in the city. More than two thirds of residents of Naujininkai, Naujamiestis and Senamiestis complain of heavy traffic and air pollution in their districts. All the inhabitants would like that more parking places be built.

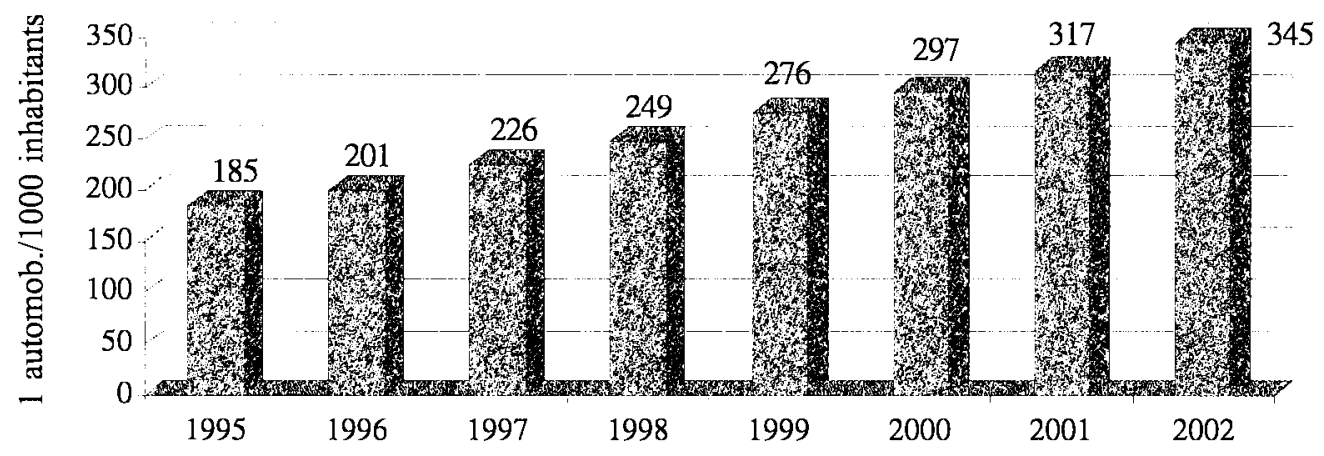

Fig 5. The number of automobiles in Vilnius, automob./1000 inhabitants 

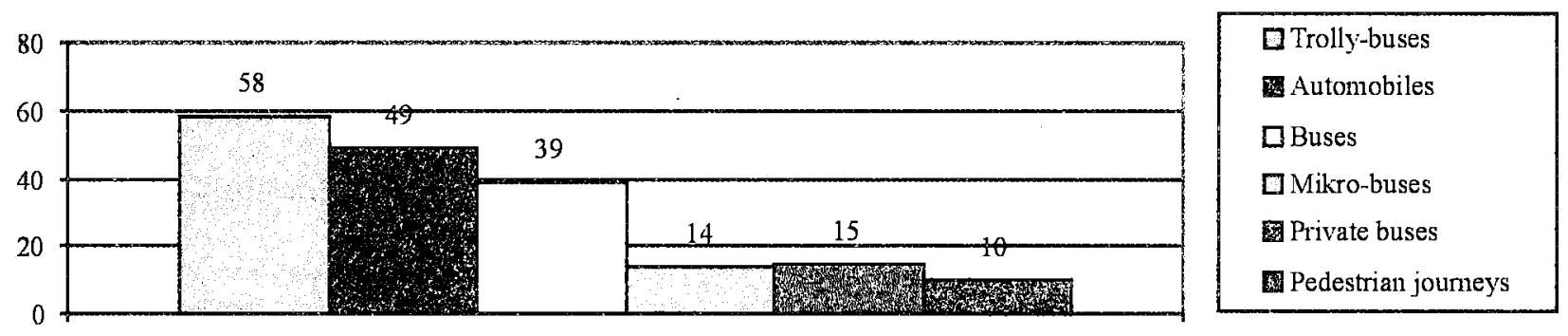

Fig 6. The choice of transport facilities in the outskirts and in the suburbs of Vilnius in 2001-2002 (\%).

Vilnius residents are particularly concerned with public transport problems. More than half of the inhabitants regularly travel by buses and trolley - buses; $42 \%$ use automobiles, while a quarter of the population travel by fixed - route taxis. To travel to work or educational institutions, people mainly rely on public transport ( $34 \%$ ), while the automobiles take the second place $(21 \%)$. The average travel time in these cases is usually $51 \mathrm{~min}$. Travel by public transport facilities takes $66 \mathrm{~min}$, by car $-37 \mathrm{~min}$ and walking on foot takes $25 \mathrm{~min}$. The people driving their cars usually run $229 \mathrm{~km}$ per week.

The residents of Vilnius support the projects of building new detours in the West and in the East as well as turning downtown and Gediminas avenue into traffic - free zone, thus reducing air - pollution and providing more space for recreation and entertainment. They also support the idea of adapting the environment in residential areas to the needs of the handicapped.

The city inhabitants demand for travel. The group of people using public transport facilities require that this system should be improved. People living in the suburbs of Vilnius would like that fixed - route public transport systems be formed and expanded, regardless of the fact that many people own cars. Newly built districts in the suburbs as well as the structure of the households and families determine the types of routes and transport facilities to be developed. Most of pensioners and socially supported people, children and students as well as a part of the working people emphasized the need for public transport services.

Trolley - buses play the main role in transporting people in Vilnius ( $57,8 \%$ of passengers). Travel by bus is mainly associated with carrying the suburbanites. Buses carry about $39,3 \%$ people, while $15 \%$ and $14 \%$ of them are transported by taxi - buses and fixed - route taxis, respectively.

In winter, $49,1 \%$ of Vilnius residents take public transport facilities, $40,7 \%$ use cars and $10.2 \%$ of people walk to their workplace. In summer, the corresponding figures are $38,1 \%, 45,8 \%$ and $15,3 \%$ (with $0,8 \%$ of the respondents cycling to work). People usually travel to work by bus ( $42 \%)$, by trolley - bus ( $30 \%$ ) and by vans (14\%). In general, $45 \%$ of the respondents rely on public transport when traveling to work and $40 \%$ use it for going to cultural events and for every - day necessities (Fig 6).

People using fixed - route public city transport facilities positively evaluate the services provided: $1 \%$ evaluate the system as very good, $30 \%$ - good, $60 \%$ satisfactory, $6 \%$ - poor and $3 \%$ have no definite opinion about it.

A survey conducted in Vilnius has revealed the influence of some factors on the choice of a particular transport facility by passengers. The use of cars is determined by the inaccessibility of public transport facilities on the route ( $22 \%$ ), the distance to a bus (trolley - bus) stop $(20 \%)$, a large interval in transport schedule $(20 \%)$, non - regular schedule $(3 \%)$, time and conditions of travel ( $9 \%)$, changing of transport facilities and incompatibility of their schedules $(9 \%)$, noise $(9 \%)$, vibration (1\%), the environment $(3 \%)$, overcrowding $(12 \%)$ and jerking motion (1\%) (Fig 7).

Most of the respondents are not satisfied with the fares of public transport services: $75 \%$ of those using private transport are not satisfied with the fares, $88 \%$ of residents using transport facilities belonging to the local government institution think that the cost of monthly tickets might be lower, while $1 \%$ of respondents think that the fare of a single journey is too high.
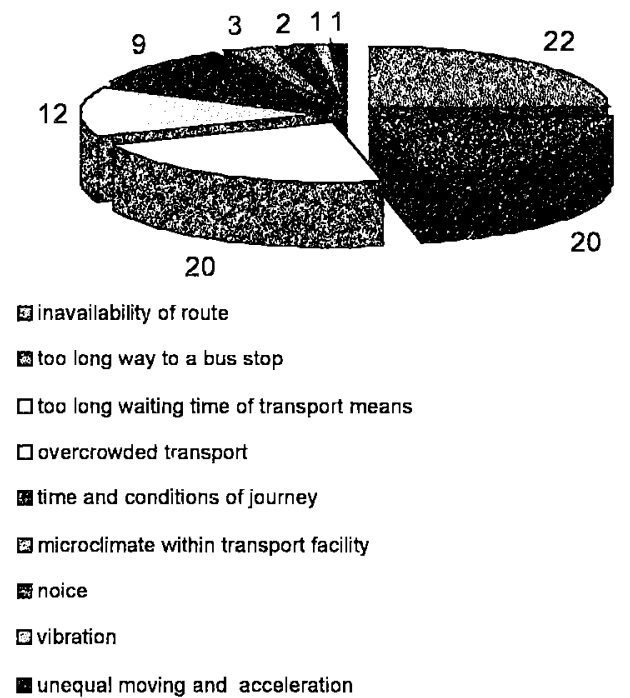

Fig 7. Conditions when preference is given to automobile 


\section{Conclusions}

1. A system of public transport services and territory structure are closely interrelated. When the territory is expanded, the transport system should also be expanded, otherwise insufficiently developed public transport will impede the development of the territory.

2. The purpose of a harmonized public transport system is the integration of various transport facilities so that passengers could choose them freely.

3. The demand for fixed - route public transport largely depends on social and economic conditions determining the need for various means of transportation satisfying the requirements of people of various income and providing the alternative to individual transport for urban travel.

4. The choice of individual transport facilities (cars) is associated with the negative aspects of public transport, i.e. non - regular schedule and insufficient amount of transport facilities, large intervals in the schedule, need for changing the carriage, noise, large distance to bus (trolley - bus) stops, vibration, etc.

5. The age, social status and financial position of the inhabitants determine the demand for transport facilities and their choice. The mobility of the residents is influenced by the location of their workplace and place of residence as well as by the nature of work and the need for business travel.

6. The suburbanites make longer journeys with more changes of transport facilities. They spend much more money and time on travel to work and other places.

\section{References}

1. Oppenheim, N. Urban Travel Demand Modelling. New York: John Wiley\&Sons, Inc., 1995.

2. European Sustainable Cities. Second edition. ECC. DG Environment. Brussels, 1998.

3. Polak, J. B.; Heertje, A. Analytical Transport Economics. University of Amsterdam, The Netherlands, 2000. 448 p.

4. Mulder, W. Biesiot. Transition to a Sustainable Society. The Netherlands, 1998, 320 p.

5. Juškevičius, P. Harmonization of Urban Planning and Urban Transport Systems Development. Vilnius: Technika, 2003. $116 \mathrm{p}$.

6. Burinskiene, M.; Paliulis, G. The analysis and perspectives of public transport. In: Development of cities and roads. Vilnius: Technika, 2000, $27 \mathrm{p}$.

7. Master Plan of Vilnius Urban Transport. Study. Vilnius, 1996.

8. Master Plan of Territorial Development of Lithuania. Transport. Vilnius, 2001.

9. Social report. MoLS, Vilnius. 2002.110 p.

10. Gruževskis, B. Major factors causing social and economic stresses and determining the employment level. LSRI. Vilnius, 2001. $39 \mathrm{p}$.

11. Sileika, A.; Blaziene, I. Differentiation of income and poverty in Lithuania. LSRI, Vilnius, 2002. 18 p.

12. Vilnius City Master Plan. Vilnius, 1999.

13. Antanavičius, V. Organizational principals of public transport. In: International conference "Urban public transport: problems, solutions, perspectives", Vilnius, 2003. 